Alex Benson

\title{
Gossypoglossia: W. E. B. Du Bois and the Pragmatics of Dialogue
}

\begin{abstract}
Even the smallest conversational turns can index macro-contexts of social inequality, racialization, and capital; fictional narrative, coordinating the particular and the global, seems well positioned to represent these scalar dynamics. But how exactly does the textual medium of the novel link the particularities of voice with the politics of race? Scholarship on this question has often turned either to the representation of vernacular speech (e.g., dialect) or to free indirect discourse, the latter as a "double-voiced" mode that linguistically concretizes Du Bois's influential theory of black double consciousness. This essay draws an alternative approach from $\mathrm{Du}$ Bois's fictional practice, highlighting the affinities between his use of dialogue in The Quest of the Silver Fleece (1911) and recent work in linguistic anthropology. In the turn-of-the-century US South represented in Quest, the functions of conversation are intricately connected with the production and exchange of cotton-otherwise known as gossypium hirsutum, giving the essay a key term, gossypoglossia, for describing these connections between a racialized global economy and particularized forms of talk. To attend to those forms is to locate theoretical resources in the very thing that critics, often dismissing Du Bois's dialogue as unrealistic or discordant, have found least compelling about his fiction. For Du Bois, the essay argues, fictional dialogue is not only (nor primarily) a site for the realist representation of conversation, but also a speculative mode in which the unspoken metapragmatic contexts of the "color-line" can be rendered explicit, unfamiliar, and subject to contestation.
\end{abstract}

KEYWORDS: W. E. B. Du Bois, dialogue, metapragmatics, double consciousness, deixis, whiteness, cotton

Alex Benson is Assistant Professor of Literature at Bard College, where he works on questions of media,
sensation, race, and ecology. He has recently published articles on Claude McKay and Herman Melville.

NARRATIVE, Vol. 27, No. 2 (May 2019)

Copyright $\odot 2019$ by The Ohio State University 
VOICE HAS LONG been a central term in scholarship that circulates around W. E. B. Du Bois. His representation of dialogue, though, rarely figures substantively in discussions of his novels and short stories. The critical record suggests two reasons for the discrepancy. The first is that Du Bois's most powerful, if indirect, contribution to literary theory may have shaped how we look at his literary practice; for over three decades, a generative if not unchallenged analogy between his concept of double consciousness and narrative "double-voicedness" has privileged the discussion of free indirect discourse. ${ }^{1}$ The second reason is an apparent consensus about Du Bois's ability to represent everyday talk: that is, he can't. To cite a few examples (I'll address others later): his early novels feature "terribly stilted language . . . in the midst of otherwise conventionally mimetic dialogue and narration" (Rampersad 69); he relies on "Victorian diction," outmoded by the time he began to publish fiction (Bell 86; Gates "Black Letters" xx; Andrews "Introduction" xxvi); and the dialogue in his first novel, The Quest of the Silver Fleece (1911) - the text on which this essay will focus-is "not merely wooden, but petrified" (Schmidt 193).

My aim is not, exactly, to deny such assessments. But I do think there's a basic question here that needs reframing. Even petrification has its strange, stony histories of transmutation. What I'm after is a way of reading Du Bois's representation of voices not by the measure of an authoritative realism, but in terms of a speculative experimentation with the ways that fictional dialogue can transmute, refract, distend, and trope patterns of conversational exchange. ${ }^{2}$ In The Quest of the Silver Fleece, those highly localized patterns interface with a large-scale economic context-specifically, the cotton industry, with all the political histories it enfolds. In the first section that follows this introduction, the central problem is how, in Quest, the localized forces of conversational pragmatics, as mediated in dialogue, also index higher-order economic structures. The second section, dividing its attention between Quest and an essay Du Bois publishes a year earlier ("The Souls of White Folk"), will track the way that those indexical orders manifest in expressions of personhood, especially in their racialization and their pronominal voicing. Throughout, my reading of $\mathrm{Du}$ Bois's fiction emphasizes its congruity with work on metapragmatics and deixis in linguistic anthropology, contributing to recent discussions linking such work to literary studies, while also asking how these models of discourse are inflected by "the problem of the color-line."3 Quest itself, though, provides the main impetus for the method here, insofar as its narrative voice not only frequently indulges in metaconversational description but also gives spatial priority to reported speech: nearly half of its thirty-eight chapters, including the first and last, end with some suggestive line of dialogue: "Oh, Harry! I-I am to be the mother of a child!" (169); "You brute! You nasty brute!" (193); "I'm thinking, she murmured, 'of buying the swamp" (198).

Set against the vicissitudes of free indirect discourse, such material might seem a crude object of analysis. If we're analogizing forms of narrative voice to forms of subjectivity, and if free indirect discourse is supposed to line up with the perspectival dialectics of double consciousness, then the analogue for dialogue would presumably be naïveté. "Discourse that has become an object is, as it were, itself unaware of the fact," writes Mikhail Bakhtin, "like the person who goes about his business unaware that he is being watched" (189). No double consciousness there, it would seem; no "looking 
at one's self through the eyes of others" (Du Bois, "Strivings" 194). Given, though, that $\mathrm{Du}$ Bois's sense of novelistic technique encompasses more than double-voiced free indirect discourse, attending to his uses of dialogue may reveal other ways of understanding how he approached fictional narrative-as, for instance, a medium for exploring the non-trivial relationships that can obtain between a racialized global economy and a little chat.

\section{"Don’t Just Blurt": Metapragmatic Variations}

A teacher passes a pair of workers in a field, nods, and shouts: "Cotton!" (Quest 10). An odd address. Still, it gets a conversation going. One of the young men in the cotton field is her student at the nearby school. As they pause to discuss the agricultural cycle, their outlines smudge into a downy singularity: "There were no persons in the conversation, just things-one thing: Cotton" (12). The topic of discussion is hardly random. Whether tenant farmer, plantation owner, senator, merchant, socialite, educator, or speculator, each of the characters in Quest lives tightly connected to this "Cotton," whose big C marks its referent not as the stuff produced by the plant gossypium hirsutum but rather as the global market in which that stuff is made commodity. Perhaps not so odd an address, then. To read this novel-at once heteroglossic and, let's say, gossypoglossic -is to listen to an economic animacy: Cotton talking to itself. ${ }^{4}$

That description of a conversation with "no persons" shouldn't be taken at face value, though. It comes in a passage of free indirect discourse whose deictic center sits on one side of the dialogue in question: that of Mary Taylor, a white Northerner who professes her anti-racism yet, as she finds herself teaching school in rural Alabama, shrinks from the blackness of her students' skin. Her primary interlocutor in this scene is her student Blessed ("Bles") Alwyn, one of the novel's protagonists, along with Zora [Cresswell]..$^{5}$ Mary's reflections on this conversation, converting persons to thinghood not by law but through a mode of exchange, come as "she began to realize that in this pleasant little chat the fact of the boy's color had quite escaped her" (12). The realization makes the forgetting a bit dubious. Did their persons disappear so completely? Bles remains sufficiently aware of their personal visibility to break away when he notices that two white men in an adjacent field are watching them. And what Mary comes to imagine as the perfect thingly immanence of their conversation seems to have depended on the mid-stream departure of its third participant-an unnamed "smaller boy" whose sole verbal contribution to the dialogue ("Goobers") names a crop other than cotton, whose nonverbal responses (cough, murmur, snort with laughter) indicate that he finds the teacher's questions absurd, and who takes off across the fields and out of the novel before his person can take on much definition in the first place (11). ${ }^{6}$ So Mary's daydream both expresses an organizing principle of this narrative-that the market influences social exchanges of all kinds in the Black Belt at the turn of the twentieth century, an influence emplotted as the interactions among those nonpersons called fictional characters-and invites doubt, tied to a fraught perspective on personhood, to a fantasy of capital without labor. ${ }^{7}$ 
One name for the attempt to parse the relationships among such interwoven and competing discursive backgrounds is metapragmatic analysis. If pragmatics describe the local interactional forces of speech acts beyond and through locution, the metapragmatic function describes those gestures and cues that reflexively link a given strip of discourse to a lexicon, register, rule, or background of appropriate speech. As Michael Silverstein writes, speakers can foreground these by directly addressing norms of discursive behavior, making "potentially presupposable context more apparent" through "denotationally explicit metapragmatic discourse." Metapragmatic cues aren't usually so explicit, though, more often - and more powerfully-emerging implicitly "in token cooccurrence patterns" (196). The men in the next field don't need to say anything for Bles to be aware of the speech norms put into play by their notice of this conversation. Or consider the powerful metapragmatic functions at work in the event of the "unasked question" that Du Bois describes in the beginning of "Strivings of the Negro People," the 1897 essay that he will reprise in the first chapter of The Souls of Black Folk (1903). Du Bois writes that he responds with tact, "as the occasion may require," to all the banal courtesies of white sympathy; but in subsequent report, he consolidates their variety into a single, higher-order question: "How does it feel to be a problem?" (194). The passage has often been described, but seldom through a simple structural fact: it articulates the implicit as explicit. The premise is that nobody who would wonder this would actually ask the question. One thing fictional dialogue affords Du Bois, I want to suggest, is a way to move such articulation out of an interpretive metapragmatic report and into a real-time interaction-and, in the process, to explore the interplay of these modes.

In the lexicon of Quest, what Silverstein calls "token cooccurrence patterns" are often described simply as languages. Though the novel does include "dialect" as that term operates in the turn-of-the-century US literary marketplace, the concept of "language" here is largely independent of orthographic variation; and the very choice of the term (suggestive of a broader compass than one might connote by, for instance, "register") underscores the weight of the social negotiations that seem to unfold whenever "language" gets invoked. ${ }^{8}$ Mr. Easterly feels uncomfortable around Mrs. Vanderpool because "she spoke a language different from his, and she had shown a disconcerting way... of letting the weight of the conversation rest on him" (135); Bles notices that as Zora spends more time at school, she seems to be "drifting away from him in some intangible way to an upper world of dress and language and deportment" (65); and Vanderpool, the school's benefactor, notices too that "the girl's language came to be more and more like" her own (134).

A complex instance occurs when Harry Cresswell-one of the men, it turns out, who had been watching Mary and Bles talk in the field-tells his sister Helen about the new teacher:

"By the bye, Sis, there's a young lady over at the Negro school whom I think you'd like."

"Black or white?"

"A young lady, I said. Don’t be sarcastic." 
"I heard you. I did not know whether you were using our language or others." (51)

Harry presumes a deictic field in which "lady" is a racialized term; when Helen denies that implicature by asking "black or white?" he does not answer but rather quotes his earlier statement ("a young lady, I said"), identifying her question as a provocation. And specifically a provocation with regard to their mutual status as White Folk"them that have become painfully conscious of their whiteness," as Du Bois puts it in 1910 ("White Folk" 339). So Helen's explicit reference to overarching "language[s]" is nested within the localized pragmatics of the act of baiting her brother (not actually, it turns out, denying his initial presumption). The implication, one that takes its locally provocative force from higher-order race and gender formations, is that she thinks of him as a person who might sometimes speak otherwise.

As Helen uses the term, a language is provisionally racialized, but this isn't uniformly the case in the novel. When Bles finishes school, he moves to Washington, DC, idealistic and ready to effect change. At a party where he had hoped perhaps to strategize about uplift, Bles is disappointed that none of the other guests want to discuss anything of political urgency. They're gossiping and talking about their kids' college prospects. He admits his frustration to the party's host, Carrie Wynn (who will later, briefly, become his fiancée):

"There are so many things to talk about," he said; "earnest things; things of importance. I-I think when our people-" he hesitated. Our? — was our right? But he went on: "When our people meet we ought to talk of our situation, and what to do and-"

Miss Wynn continued to smile.

"We're all talking of it all the time." (139-40)

She explains that although they "veil it a little," everyone at this party is thinking about the same thing. "You haven't learned our language yet. We don't just blurt into the Negro Problem; that's voted bad form. We leave that to our white friends. We saunter to it sideways, touch it delicately because'-her face became a little graver-'because, you see, it hurts"' (140). Carrie is not alone in observing that "a dialogue may be implicated by being conspicuously avoided," as in Judith Irvine's description of "shadow conversations" (152), and Bles provisionally capitulates. "I-I think I understand" (140). If Carrie is trying to educate him head-on in this language, though, there are also quieter cues in her speech. Whereas he had stumbled on the first person, both singular ("I-I think when our people"; "I-I think I understand") and plural-possessive ("was our right?"), Carrie measures out her explanation of "our language" with the thrum of an anaphoric we, implying the reality of the discursive community Bles finds dubious: "We don't just blurt ... We leave that ... We saunter to it." We strike straight meets tell it slant. ${ }^{9}$

Soon made part of the "we" from which he had felt distinct, Bles's status in DC quickly rises, and he becomes the favored candidate for a Treasury position. This will all go away when he refuses to linguistically saunter. He gives an impassioned com- 
mencement speech that the newspaper describes as a "Vicious Attack on Republican Party by Negro Orator" (175). His DC career is over before it begins. He asks Carrie to come South. She won't. The introduction to the recent Oxford edition of the novel singles out this moment as an example of how "dialogue in the novel can sometimes seem archaic and artificial. As she kisses him goodbye, Wynn intones, as if from the King James version of the Bible, 'Bles, almost thou persuadest me-to be a fool"' (Andrews xxvi). She is not just speaking "as if” from the King James Bible, though. She is citing Acts 26:28: "Then Agrippa said unto Paul, Almost thou persuadest me to be a Christian." In parallel with Paul's orations about his conversion to a series of audiences, including Agrippa, while in imperial captivity, Bles speaks too boldly. Like the King of Judea, Carrie shows interest to a point. Also like him, she's only going to tarry so long with a martyr. What makes her line seem out-of-joint in its register is the parodic citationality of her complaint that Bles is too old-fashioned and too self-sacrificing. A reader may feel that this complaint confirms Carrie's description of herself as "selfish and-small" (177). But we overlook the plurality of discursive norms that her utterance negotiates-the language of Acts, the self-care strategy of sauntering circumspection, the social and financial demands of a tenuous position in the bourgeoisie-if we read her style as a symptom of Du Bois's own "debt to literary gentility" (Andrews xxvi). Reading a tone as a debt, after all, reproduces a link between discursive style and financial credit that is itself at issue in this plotline: Carrie dumps Bles because she speculates that his "fool speech" would cost him "between twenty-four and forty-eight thousand dollars" in future income, a "bargain" that might work for Bles but doesn't for her (176).

The relationship between debt and discourse becomes even more pointed in the agricultural context. In the chapter of Souls whose title Du Bois adapts for that of this novel, "Of the Quest of the Golden Fleece," he identifies the manipulation of tenant farmers' finances, and thereby the reproduction of an indebted labor force, as a crucial instrument of post-Reconstruction Cotton, the "slavery of debt" that sustains "an all-cotton scheme of agriculture" (101). ${ }^{10}$ In chapter 17 of Quest, "The Rape of the Fleece," Du Bois personifies this instrument through Colonel Cresswell, who consults with his clerk about how to keep all of his tenant farmers at just the right level of debt so that they will be able to keep producing but not to leave (98). In the biopolitical formulation of a Georgia planter who described the tactic in 1913, "his labor has 'just lived." "' Zora herself, at the end of the same sequence, comes to the Cresswells' to sell three thousand pounds of cotton so gorgeous that "idlers, black and white, clustered round, gazing at it, and fingering it with repeated exclamations of astonishment" (99). Yet she leaves with a receipt that says she still owes twenty-five dollars for rent, purchases, and arrears (101). That calculation is performed by the Colonel's son, Harry Cresswell, who years earlier had sex with Zora when she had been forced into child prostitution, and, in this moment, his power over the terms of the sale is inseparable from his control of the spread of talk about this background. The same person who exploited her sexually adjusts her debt so that she has "just lived." Her response- "in awful earnestness, she turned toward the future" (101) - might suggest the ironically radical possibilities of living "in debt forever," a sense of being "good already in the mutual debt that can never be made good” (McLanahan 197; Harney and Moten 20). 
Later in the novel, when Zora is in the process of establishing a collective planting enterprise, she herself analyzes the connection between discourse styles and credit; she won't be able to get a bank loan, she predicts, because she "can't talk to rich white folks the way they expect us to talk" (198). As she implies, the valuation of an utterance is a function at once of localized stylistic norms and larger markets. Like commodities, talk circulates-a likeness vividly evoked by a description of the town market: "Cotton was currency; cotton was merchandise; cotton was conversation" (99-100). And the exchange of cotton and conversation, of gossypium and gossip, involves speculative valuations, of stuff and of persons and of the futures of each, that unfold not only in parallel but in codetermination.

In a novel about cotton, it is no surprise that the points at which the material and the linguistic construction of commodities most closely intersect often have to do with clothing. A cotton dress embroidered with silk plays an important role at several moments, and when Bles and Zora go through adolescence, the narrator describes it as a process where the soul, coming "suddenly to consciousness of body and clothes ... gropes and tries to adjust one with the other, and through them to give to the inner deeper self, finer and fuller expression." The visual manifestations: "Alwyn's Sunday suit, vivid neckties, and awkward fads" (63). Self-transformation is modeled here as a triangulation of interior, body, and commodified object. A similar triangle forms the basis of Michael Silverstein's account of the forms of self-presentation that go into "wine talk," oinoglossia. In identifying oakiness and so on, Silverstein writes, wine talkers also aim to imply their own qualities, the sensitivity—in Du Bois's words, the "inner deeper self"- presumably required to coordinate a subtle fleshly palate with an elaborate lexicon. This "yuppie" register, when it's working as intended, produces an iconic resemblance between wine and self, a "culturally eucharistic" consubstantiation that is a "microcontext of higher-order indexical authorization" (226). While the real-time performance of connoisseurship and ease in an elevated register may construe a person as an authority in the moment of the tasting, this localized performance also invokes large categories of, for instance, class and regional identificationinvocations that can misfire or go astray, as in the "awkward fads" of Bles's attempt to sartorially express the shifting contour of his body and soul.

Commodity appreciation can thus serve diverse social ends. When Bles shows up at Carrie's party in DC (just before she tells him to saunter), he is wearing one of his "vivid neckties" (63). It is a recent purchase, a real favorite, and a choice over which he long deliberated. It is also unfortunate. Luckily, if no more fashionably, he is the first guest to arrive. As he and Carrie begin to "talk . . . about generalities," she sees an opportunity. "She conducted the conversation by devious paths to ties and asked Alwyn if he had heard of the fad of collecting ties. He had not" (138). Through this commodity talk, she is able to save face for him by avoiding the awkward experience, at the first indexical order, of telling him his tie is too vivid for her party. Instead, she says it would make "just the dash of color" to complete the look of her new pillow. He offers to send it at a later date; she proposes to trade him another on the spot. ${ }^{12}$ Once this substitute is around his collar, Bles thanks her, but only after a pause that seems to suggest he is not thanking her for the accessory but for the discretion of the rescue. To be clear, though, my account, any account, of his recognition at this moment-the 
moment when he sees himself through his interlocutor's eyes-must make do with inference. Du Bois does not detail this moment of Bles's subjectivity through indirect or free indirect discourse; rather he indicates the higher indexical orders of the exchange only inside quotation marks: "You see," Bles says, "in the country we don't know much about ties" (138). While the ties are probably made of silk, what's being valued in their exchange has everything to do with how these interlocutors differently relate to Cotton.

Pointing this out directly involves, for Bles, a dance of discursive authority. He claims one form of ignorance so as to claim a different form of insight. The phrase "you see" walks this tightrope, cuing up the speaker's own explanation in a form that pays lip service to his interlocutor's own prior understanding-and specifically her visual aptitude, appropriately for the situation (she saw his terrible tie). By making the metapragmatics of the situation explicit at an indexical order a few levels up (city versus country) from their immediate circumstances, Bles also shifts the first-order pragmatics of their interaction: Carrie is thrown off balance by his directness, "los[ing] her aplomb" (138). She finds her footing quickly, though. Soon after, when she gives him instructions for (not) talking about the Problem in the exchange I discussed earlier, she will trade his effective second-person construction back to him: "You see, it hurts." This second "you see" is both an address and a reference, both a personal intimation and a linguistic echo. The phrase rhetorically serves Bles, the advocate of talking about one's situation, and then Carrie, the censor of blurting into it.

That functional travel suggests the dynamically responsive capacities of multiple "languages" to encompass, repurpose, and be shaped by given lexical units; to adapt Du Bois's description of adolescence, in language use one "gropes and tries to adjust one with the other," utterance with register. ${ }^{13}$ If this describes the Cresswell siblings' negotiation over "lady," it also describes the way that Quest itself uses the term "language." With an eye to the question of such linguistic adjustments across Du Bois's own body of work, then, as he elaborates concepts and images across the boundaries of text objects, I'll begin the next section with a reading of a few key passages from an essay he first published the year before Quest-the same year, that is, that the manuscript of this first novel, the one he started writing soon after The Souls of Black Folk, finally came into shape for publication. This reading will continue to track Du Bois's interest in how localized moments of pragmatic negotiation intersect with the macrocontext of a racialized economy, but with a turn that Carrie Wynn might endorse, moving from Du Bois's use of dialogue to draw metapragmatics out into the field of blurting denotation to more implicit saunters, especially those realized, as in the phrase Carrie trades back to Bles, through distinctive patterns of pronoun use.

\section{“And Am No I": Personal Deixis and Indirection}

Though "The Souls of White Folk" would be collected, with deep revisions, in Darkwater (1920), it first appeared in The Independent in 1910. Here Du Bois directs his attention to "those in whose minds the paleness of their bodily skins is fraught with tremendous and eternal significance" (339), a fantasy subtending their faulty 
claim to "title of the universe" (340). In fact this myth dates, in Du Bois's account, to the nineteenth century, and in four pages of print he makes the case that this "very modern thing," "this new religion of whiteness" (339), is incompatible with social equality, global democracy, scientific knowledge, and Christian morality. The essay concludes by personifying the archetypal White Folk as a Promethean thief whose cry of "I am white!" "reverberat[es] thru the world" (342). Du Bois's response- "Well and good, O Prometheus, divine thief"--dampens this reverberation by juxtaposing registers; the Romantic apostrophe to the mythic figure, "O," sounds sarcastic after a colloquially dismissive "well and good." The seemingly rhetorical question that ends the essay suggests a similarly deflating pacification: "The world is wide enough for two colors ... why then devour your own vitals when I answer, 'I am black'?" (342).

In the 1920 version, this question will become an imperative: "Why, then, devour your own vitals if I answer even as proudly, 'I am black'” (52). But in the Independent, the concluding exchange- "I am white!"; "I am black" - strongly echoes an early passage in the essay, one not included in Darkwater. In this passage Du Bois attempts to explain the inexplicable modern celebration of whiteness through "the analogy of the child and his candy." Children, Du Bois notes, enjoy candy. Then, at a second stage, they may greedily enjoy having candy and knowing that somebody else doesn't. Finally, with their mother's instruction, they mature to the "third new joy of sharing." But in this bonbon dialectic whiteness won't sublate. The constant refrain of whiteness "sounds like: 'I shall keep my candy and you shall not have yours.' Or, in other words. it is not the obvious proposition: 'I am white and you are black,' but the astonishing declaration: 'I am white and you are nothing"' (339). ${ }^{14}$ This sets up a possible answer to the question that ends the 1910 version, an answer that does not fully reduce to the idea that "the world is wide enough for two colors" (342): the white Prometheus may devour his own vitals when he hears the statement "I am black" because, on his own logic, the likely follow-up to such an utterance is and you are nothing. ${ }^{15}$

In the wildly imagined conversation that immediately follows the candy analogy, $\mathrm{Du}$ Bois takes the idea of this rhetorical reversal and, I'll suggest, plays out what it would look like not as an utterance, nor as an implicature, but as a mode of representation. He writes that the belief that "whiteness alone is candy to the world child" produces strange interactions like the following:

even the sweeter souls of the dominant world, as they discourse with me on weather, weal and woe, are continually playing above their actual words an obligato of turn and tone, saying:

"My poor un-white thing! Weep not nor rage. I know, too well, that the curse of God lies heavy on you. Why? That is not for me to say; but be brave! Do your work in your lowly sphere, praying the good Lord that into heaven above, where all is love, you may, one day, be born-white!"

At such times I have an unholy desire to laugh, and to ask with seeming irrelevance and certain irreverence:

"But what on earth is whiteness, that one should so desire it?" Then always, somehow, some way, silently but clearly, I am given to understand that whiteness is the ownership of the earth forever and ever, Amen! (339) 
As in the "Strivings" passage about the "unasked question," Du Bois begins with actual if generalized (iterative) everyday chatter about "weather, weal and woe." He then moves to an imagined transcription of the obligato message ("be brave!") that is implied but not uttered in all that ad libitum small-talk. So far, the conceit remains close to "Strivings." But then Du Bois takes it further. He responds as though this message had actually been uttered, holding back laughter and a question. ${ }^{16}$ And in response to his own unasked question- "what on earth is whiteness"?- he receives a response that is just as implicit as the opening obligato message of pity. Whereas that initial implicature was figured as music playing above real speech sounds, "actual words," this final communication happens "silently", unanchored in anybody's utterance. By the end of the passage, in the whirl of Du Bois's analysis, any sense of an interlocutor, even an avatar of these "sweeter souls" in aggregate, has vanished. Making the apparent dialectic of the conversation immanent to his own interpretation-an "inner speech" that "resemble[s] the alternating lines of a dialogue" (Vološinov 38)- he has gradually shifted "the sweeter souls of the dominant world" into the nothing-position that they reserve for the second-person addressee. ${ }^{17}$

Linguistically, it's usually third-person pronominal reference that is understood not to index personhood, insofar as that category presumes a basic deictic reciprocity. "I use I only when I am speaking to someone who will be a you in my address," according to a foundational account, and "it is this condition of dialogue that is constitutive of person" (Benveniste 224). Thus outside the first and second persons lies "a realm of nonpersons" (Irvine 143). Greg Urban, meanwhile, posits an important qualification through the "anaphoric" (with a semiotic emphasis on referentiality, rather than a poetic emphasis on repetition) use of the first person: in reported speech, "I" does not directly index the speaker, but its use can nevertheless suggest an imitative, identificatory, or metaphoric relationship between first and third persons (34-36) - that is, between persons and grammatical "nonpersons." In other words, even in theatrical or citational instances of "I", its utterance can sometimes indicate something about the speaker, and not only their referent.

Perhaps the most idiosyncratic usage of pronouns in Quest comes in the voice of John Taylor, Mary's brother, who embodies a particular form of white Prometheanism. The narrator introduces him as one of the "tense silent white-faced men" who move among the cotton fields where laborers sing their "Song of Service," but who unlike those laborers "felt no poetry and heard no song" (25). ${ }^{18}$ John's scheme to "own the cotton belt of the South" (57) through the manipulation of financial futures and the consolidation of land ownership makes him the "spiritual heir" of his former mentor Job Grey, whose masterful manipulation of the cotton market-to his personal gain but to others' injury worldwide, from starving Alabamans to freezing Siberiansearns him a comparison to Milton's Satan (25). ${ }^{19}$ But John is no rhetorical virtuoso; he's more like the capitalistic Zeus Du Bois describes in the "Work and Wealth" chapter of Darkwater: a man "from the North ... who held all the thunderbolts of modern capital in his great fists ... who saw nothing, knew nothing, sought nothing but the making and buying of that which sells" (83). Seeing, knowing, and seeking nothing but production and exchange, oblivious to the vocal arts of poetry and song, John seems to live at a stylistic degree zero. 
But his voice does have a style. John first appears in a conversation, given in flashback, with Mary as she decides whether to take the teaching job in Alabama. Newly interested in cotton, John encourages her:

"Better go," he had counselled, sententiously. "Might learn something useful down there."

$[\ldots]$

"But, John, there's no society-just elementary work-"

John had met this objection with, "Humph!" as he left for his office. Next day he had returned to the subject.

"Been looking up Tooms County. Find some Cresswells there-big plantations - rated at two hundred and fifty thousand dollars. Some others, too; big cotton county."

"You ought to know, John, if I teach Negroes I'll scarcely see much of people in my own class."

"Nonsense! Butt in. Show off. Give 'em your Greek—and study Cotton. At any rate, I say go." (9)

John's pithy speech omits the second person not only in the imperative ("Butt in"), where its omission is grammatically "standard," but also when suggesting a course of action where its omission is nonstandard, if not uncommon ("[you had] Better go"; "[you] Might learn something useful down there"). More conspicuous, though, is his general omission of the first person, as in "[I have] Been looking up Tooms County." Examples abound in the novel, but by way of brief illustration here are a few more in reference to Mary: "Have a sister who is-er-devoting herself to teaching them" (26); "Should like to have you meet and talk with my sister" (27); "By Jove! Forgot all about Mary" (58). John does, it should be noted, use "I" at any number of moments in the novel; he does so, for instance, when he seconds his own advice in the passage above ("I say go"); when he testifies in court (226); and when he misses the start of a business meeting because he is flirting with Helen Cresswell (that is, sketching agricultural equipment for her), and, embarrassed to be found doing so by Harry, can only stammer: "Well-I_ . . Why, Miss Cresswell, I_I_-" (59). What I'm describing is thus not a static rule but an intensity in a certain direction, a pattern of token non-occurrences (deviations from which pattern would also merit localized attention). Dynamically emergent and recessive, this pattern of avoiding the first person is not conspicuously disruptive of realist conventions. Neither is it neutrally reflective of an incidental behavioral habit. Rather, for Du Bois, I believe, it mediates a particular metapragmatics, a concept of whiteness not only in Mary's sense in the passage above-as "society" of her "own class"- but more specifically as a form of expropriative personhood. ${ }^{20}$

We might simply call John Taylor's speech Taylorist, a vocal cousin of the streamlining of laborers' gestures prescribed in a text published the same year, Frederick Winslow Taylor's Principles of Scientific Management (1911). John is a gossypoglossic machine who can cite to the cent the amount and repayment schedule of the Cresswells' debt (59); he "talk[s] cotton ... mechanically and from long habit" (58), so much that his sister Mary teases that "John is nothing but cotton ... his soul is fibrous" 
(41). "Fibrous" suggests a texture, something made of threads, capable of being pulled apart, and a little fleshy, figuring John's soul in a term that could also describe its wrappings, both body and clothing. Calling John cotton all the way down and back up, Mary suggests the thin line between being unmarked (as in Ruth Frankenberg's account of white exceptionalism) and being nothing. And in contrast to the white Prometheus who cries out "I am white!" to the world, John is cagey, perhaps savvier or more anxious about the potential anaphoric slippage or reciprocity of first-person reference. What looks at first glance like the efficient grammar of the capitalist's indifference to personality, then, starts to sound like a paradoxical expression of this claim to whiteness, one that attempts to maintain "the ownership of the earth forever and ever" by keeping its candy as quietly as it can. This non-reference is the stylistic expression of his sister's daydream, early in the novel, about the structure of her chat with Bles as a conversation with no persons. This is how Cotton talks to itself.

Which brings us to one more possible reason-besides political modulation or the impulse to sober things up by deleting the candy-that Du Bois cuts that arresting line about "nothing" when he revises "The Souls of White Folk." Or rather, perhaps he doesn't cut it; he moves it. The apocalyptic short story "The Comet," also published in Darkwater, opens with the protagonist, Jim Davis, standing "on the steps of the bank, watching the human river that swirled down Broadway. Few noticed him. Few ever noticed him save in a way that stung. He was outside the world-'nothing!' as he said bitterly" (253). Compressing a paradox Samuel R. Delany will express in Dhalgren, "here I am and am no I" (57), Du Bois takes the idea of being nothing and, routing it through the first person that is implicit in reported speech, ironizes it to the verge of impossibility. The experience of double consciousness gets voiced here both in free indirect discourse-the double-voiced representation of feelings sometimes understood to take place, themselves, "outside the world" - and also in a single word inside quotation marks. ${ }^{21}$ Fiction makes nothing happen; fiction makes "nothing!" happen. ${ }^{22}$

When it happens is another question. Jim Davis seems to say "nothing!" on the steps as the vocalized conclusion of a train of thought so bitter it has to be blurted out in quasi-public speech, a two-syllable soliloquy. But the passage also quietly allows for the sense that this is something "he said" habitually_an iterative pattern rather than a singulative event-in response to the general fact that "few ever noticed him." ${ }^{23}$ This would suggest not an outburst but a conversational pattern, a context or community for talking about "things of importance," in Bles's words. So this "nothing"-more specifically, its re-entextualization in dialogue-suggests how the temporalities of reported speech can entail modes of social relation, of alienation or belonging.

Since, in Quest, Du Bois uses the romance plot to think through the possibilities, obstacles, and temporalities of such belonging, I'd like to finish by discussing three brief exchanges from across that arc. In chapter one, during their first meeting in the swamp, Zora says to Bles: "We'se known us all our lives, and-before, ain't we?" (3). If this strikes a reader as a surprising thing to say within a few minutes of meeting someone, yet another mimetic lapse, Du Bois places a similar reaction at the end of the chapter. After they part ways, Bles wonders in confusion, "Had he seen a haunt? Or was the elf-girl real? And then he thought of her words: 'We'se known us all our lives"' (5). While we aren't told what, if anything, Bles understands about her utterance-or 
what sort of answer it provides to his question about her reality-the particulars of his recall may offer ways to infer. Notice, for instance, that Bles edits out several words: "and-before, ain't we?" The line's phantom ending, cut here but extant in the space of the novel, opens a shadow conversation about the metapragmatics of the first-person plural, about a prehistory ("and-before") of entanglement that doesn't fully map onto Cotton's territory. ${ }^{24}$

But Du Bois also thinks through how presupposed structures of relation, including those of novelistic genre, can have baleful effects. The romance plot hits the obstacle of grotesque misogyny when Bles hears that Zora is not "pure" (90); in fact, it's Harry Cresswell himself who has told Bles she is "notorious," while leaving out his reasons for saying so (88). In rejecting Zora (to whom he'll later propose, only to get turned down, until she finally proposes to him), Bles is vile: "You should have died" (90). For Keith E. Byerman, although at this moment "the dialogue could be taken from almost any sentimental novel, and in most the fallen woman would in fact die," $\mathrm{Du}$ Bois then transcends that boilerplate, using this split to expand the novel's universe, with Zora at its center (124-25). ${ }^{25}$ The radical plot overrides the tired genre cues of the dialogue, one might say. Reading Bles's line as hyper-conventional downplays both its eccentricity and its menace, though. While he may express a novelistic convention, it seems less plausible that such an utterance would often appear in sentimental novels or other texts that mobilize the fallen-woman plotline. By making these generic metapragmatics oddly explicit at the level of the character's utterance-and in so doing collapsing the particular "you" that is Zora with an anaphoric "you" that has a citational relationship to a nonpersonal type-Du Bois also registers the set of implicit metapragmatic parameters that are the intertwined histories of racial and sexual violence in the US. In a novel whose penultimate chapter tracks the movements of a lynch mob, the literary convention cited in Bles's outburst complexly coincides with the necropolitics of the post-Reconstruction nadir, through the long history of sexualization and torture that Hortense Spillers describes as deriving from the slave trade's "theft of the body" (67). ${ }^{26}$ So Bles's line is not, I'd suggest, best understood as an incidental stylistic deficit to be balanced out when Zora, as in Spillers' exhortation, "gain[s] the insurgent ground as female social subject" (80). It is rather a marker, partial and brutal, of what such insurgency contests.

That sense of contestation reverberates even in the (near-)resolution of the romance plot. When Bles tries to tell Zora who he is in love with-her-he uses an ambiguous third-person form ("The best woman in the world, Zora") and then they take a few quasi-vaudevillian turns each referring to a "she" who is actually, depending on which one of them is speaking, either "I" or "you." Once Zora sorts it out, she asks, overcome, "Will you-marry me, Bles?" and the novel ends there (238). Unlike "Reader, I married him," the outcome is unspecified (Brontë 468). Like it, the addressee is conspicuously marked: if Zora's mid-question pause ("Will you-") suggests the depth of her feeling, it also decelerates on the second-person pronoun in a way that might help attach the grammatical shifter to the person it hails-yes, you-in a dialogue that has received its affective energies precisely from the difficulty of securing such indexical reference. Bles's withholding of personal deixis here quietly reopens the question about "real" personhood expressed both in their first meeting 


\section{Alex Benson}

(when he wonders whether she is a "haunt") and in his invective against her (where he takes her survival, the fact that she has "just lived," as an improbable affront). And though the text of the novel proper ends with Zora's question, immediately after it $\mathrm{Du}$ Bois places a closing "Envoi" in which these same affective and deictic troubles carry through, only now extended along the axis of author and audience. "Lend me thine ears, O God the Reader," writes Du Bois (closer to Jane Eyre, now), "whose Fathers aforetime sent mine down into the land of Egypt." With a repeated "O" that may have some of the irony it did in "White Folk," Du Bois-insisting that the story has been no "phantasy," but doing so in a register far from realism-asks the reader to look up from the page at "the horror of this land," at the torture, he implies, of modern Israelites, and to do something about it: "Let my people go, O Infinite One" (238). This addressee's "infinity" suggests its power but also its indeterminacy. Any given instance of l'envoi's reception by one of its infinite possible readers opens the question of the political future on which that reader is intent. Du Bois's first novel thus closes with a thought about its own reception that is also, and perhaps better, expressed within its last line of dialogue: "Will you-."

\section{Conclusion}

In $1940 \mathrm{Du}$ Bois looked back at Quest as "an economic study of some merit" (Dusk of Dawn 134-35). Given the place of the economy that it studies within the history of modern inequality - as Du Bois writes in Black Reconstruction, the systemization

of slavery unfolded in tandem with the expansion of "the Cotton Kingdom . . . into imperial white domination" (7) - my angle of view in this essay may have seemed a little acute. This impression might be intensified in contrast with assessments of Quest as an "epic" or as a key transitional text in Du Bois's effort in the 1910s to conceptualize a "great global struggle to make multinational capitalism more democratic and less monopolistic" (Rampersad 70; Schmidt 194). And there remain more ways still to receive this narrative on the widest frequencies-as an entry in the history of that hyperobject (in Timothy Morton's term) called Cotton; as an intervention in an urgent conversation about how to live within, outside, or against the accelerating proliferation of plantations across the face of the Earth (in Anna Tsing's terms); as an attempt "with Beauty and for Beauty to set the world right" (in Du Bois's terms; "Criteria" 995). There's no shortage of indications that Du Bois was also compelled, though, by the other end of the scalar thought, by the way that the smallest signs carry planetary burdens, by "the dialectical plenitude of indexicality in micro-contextual realtime" (Silverstein 227).

I'd venture that this compulsion offers a strong explanation for the fact that he wrote novels at all. What narrative fiction allows Du Bois to do-in ways that incessantly intersect with, but are distinguishable from, both the literariness and the propagandism of his other modes of study-is less to realistically transcribe the dialectical plenitude of conversation than to speculatively animate and distribute it. ${ }^{27}$ In dialogue he gives particularized voicing to premises of social relation that usually go unspoken and shows how seemingly extralinguistic phenomena might 
be invoked syntactically. If metapragmatics can help describe these transmutations, in turn Du Bois's first novel insists on their connection to levels of affective distortion, violent eventuality, and fibrous entanglement-that is, the experiential world a gossypoglossic language presupposes-that one might want to call subpragmatic. The choices of register that flow from this insistence may not have helped his reputation as a stylist. And we need to keep thinking about how the racialized economies of canon formation shape such interplays of register and reputation. More narrowly, in the case of Quest, it seems likely that Du Bois's experimentation with the speech genres of his characters has, "somehow, some way, silently," influenced critical evaluations of his own novelistic voice, in the way that the anaphoric I of third-person reported speech can be taken to index something about the person who animates it-or the way that Mary Taylor's dream of an all-Cotton conversation makes a mark on her, too. I hope to have suggested a way of reading such marks as points of articulation between literary and socioeconomic forms.

\section{Endnotes}

1. Gates's analogy between double consciousness and free indirect discourse ("a dramatic way of expressing a divided self"), developed most directly in a reading of Hurston, travels widely in studies that engage with Du Bois (Signifying 207). For a synthetic, critical interpretation of models of double-voicedness-as they construe (and conflate) language and literature, individual and collective-see Hale, Social Formalism (197-220) and The Novel (454-59). See Reed for a polemical argument that double consciousness was not in fact "a key organizing principle of [Du Bois's] thought" (124). On voice in Du Bois's thought see also Gooding-Williams on Du Bois's expressive politics; Stoever on the metaphors of veil and vacuum in terms of sonic mediation; and Wall on $\mathrm{Du}$ Bois's incomplete representation of the sorrow songs as entailing an ongoing engagement with vocal tradition.

2. By referring to the "speculative" here I mean, in part, to link the salutary attention recently paid to $\mathrm{Du}$ Bois as a writer of speculative fiction in the world-building Afrofuturist mode (see Brown and Rusert) with a sense of his more granular interventions in or against realist conventions. The debates about "natural" versus "unnatural" narratology that this may evoke have been discussed more fully than I can develop here, especially in prior issues of this journal; I'll briefly note that, while both macro- and micro-speculative may violate "mimetic expectations and the practices of realism" in ways that Richardson describes as "unnatural" (3), it would be fair to describe several of my readings-which use the analysis of indexical order to resolve apparent stylistic anomalies-in terms of the "naturalization" that Fludernik outlines in, for instance, her synthesis of claims by Culler and Yacobi (360). "Speculative" is also a loaded term in its connection to financial futures; on "the speculative economy surrounding textiles - and particularly silk and cotton" and "the novel [as] a fiction of capital," see Holt (120), while McInnis's excellent recent article on ideas of the plantation in Quest works toward integrating its world-building and economic angles of speculation.

3. Souls 3. On literary studies and linguistic anthropology, see the special issue of Representations edited by Lucey, McEnaney, and Wolff. A genealogical connection links metapragmatic analysis and $\mathrm{Du}$ Bois, through his loose cohort in pragmatist thinking and a key figure in anthropological semiotics, Charles Sanders Peirce; on Peirce and processes of entextualization see Lucey and McEnaney's introduction to the same special issue ("Language-in-Use and Literary Fieldwork" 1-22, esp. 7). 
4. See Pietz on the fetish as "a material space gathering an otherwise unconnected multiplicity into the unity of its enduring singularity" (7). My neologism develops from both Bakhtin's term and from Michael Silverstein's oinoglossia, to which I'll return later in the essay.

5. I bracket Zora's surname because the novel refers to it only once, in the non-neutral context of a court proceeding (226).

6. "Goobers" is a complex term here as a Bantu retention in a regional English (on the word's implication of "proximity to the black folk," see Baker 23), and also insofar as peanuts have served as both a rotator crop enabling mass cotton production and as a resource for foragers.

7. On this fantasy, see Harney and Moten 90. On personhood, the law, and literary form, see Best, who writes that "slavery is not simply an antebellum institution that the United States has surpassed but a particular historical form of an ongoing process involving the subjection of personhood to property" (16).

8. As Kunreuther notes, "moments when people talk explicitly about voice or speech" often reveal the interplay of "social conflicts and diverse subjectivities" (246).

9. "We / Strike straight" is, of course, from Brooks (73) and "tell it slant" from Dickinson (506).

10. On the political history of state and national debts in the postbellum period, see Du Bois, Black Reconstruction.

11. My 1936 source for this quotation (Kester 42) concurs closely with Du Bois's account of the commissary as a site for managing laborer debt. (Thanks to Miles Rodriguez for drawing my attention to Kester.) On the same practice, see Beckert 286-87.

12. Like Bles, the narrator of Johnson's Ex-Colored Man, published the year after Quest, loses a tie of "odd design" $(45,61)$ - the theft of which, along with three hundred dollars, deters him from matriculating at Atlanta University, an institution strongly associated with Du Bois.

13. See Agha, building on Goffman's model of footing: "we cannot understand macro-level changes in registers without attending to micro-level processes of register use" (38). This insight raises further questions at the level of the object of the novel itself, directing us toward the tissue of exchanges and substitutions that go into processes of entextualization. To the extent we take the novel itself as a commodity, in other words, it's one whose seeming reification unfolds in continual relationship to other strips of discourse, a relationship sometimes visible in the small adjustments in valence of utterances internal to the novel-that is, "micro-level processes of register use." On entextualization processes see Urban and Silverstein's introduction to Natural Histories of Discourse (1-17, esp. 12-17) and Tristam Wolff's "Afterword" in Lucey, McEnaney, and Wolff (167-73, esp. 170).

14. Marable, in a crucial book on Du Bois, is one of few scholars to comment on this passage; my only quibble with his description is that he refers to an "equation" between these two statements (64), whereas I take Du Bois's point to be precisely their non-equivalence.

15. My reading of Du Bois's final line here differs from Hickman's account (see 19-21), perhaps due to the differences between the 1910 and 1920 versions of the essay (the latter of which Hickman cites).

16. This line is significantly revised for Darkwater. Du Bois substitutes: "I do not laugh. I am quite straight-faced as I ask soberly:" (30). The subsequent question, though semantically identical to the 1910 version and though still responding to a statement that was only implied, is now framed as an actual (rather than potential) utterance. Meanwhile, his own desire, denoted in the 1910 version, is now only implied: he says he does not laugh and thereby suggests that he wants to. So it is now the writerly voice that carries a second musical line of implicature; the muddy interplay of semantics and pragmatics denoted in the "seeming irrelevance" and "certain irreverence" of the 1910 version is now, in revision, instead connoted by the tone of report. In these comments I have 
in mind Napolin's account of narrative discourse as "a figural voice that displaces, but cannot fully overcome, its acoustical associations" (116).

17. Later in the essay, he offers a different image of his encounters with White Folk (the difference of which may be attributable to Du Bois's distinction between those souls that are "sweet" and those that aren't): "before me the Souls of White Folk stand singularly naked. In my presence they tend to lay aside all their little lies and hypocrisies and bathe in brutal frankness" (341).

18. See Elder on the "Plantation viewpoint" (361) that John typifies (362).

19. Du Bois quotes from Milton (with a few tweaks): "High on a throne of royal state, which far / Outshone the wealth of Ormus or of Ind" (28, lines II.i-ii).

20. My approach here is influenced by Lucey's argument that the pointed absence or "abstraction" of the first person in twentieth-century French literature can index obstacles to "self-authorization in statements regarding same-sex sexuality," while revealing "the social implications and the formal characteristics of their enunciation" (Never Say I 22, 23).

21. While many models of free indirect discourse would deny that it occurs "outside the world," we can see this idea in a recent application of Gates's model of double-voicedness to Du Bois's own fiction; about the "Coming of John" chapter of The Souls of Black Folk, Gooding-Williams writes that "free indirect discourse ... invests black John's state of mind with a dramatic immediacy that sets it apart from the worldly actions surrounding it" (278 n. 8).

22. Playing on Auden's famous line about Yeats, Barbara Johnson, in a reading of Mallarmé, writes: "Poetry makes nothing happen; poetry makes nothing happen" (30).

23. On Genette's iterative/singulative distinction in a literary-historical context close to Du Boisespecially close given the generic overlap of Quest and The Octopus, often compared as epics about commodities-see Brown on Norris's McTeague (ch. 2, esp. 208 n.19).

24. See Moten's work on the relationship between individuation and sociality in (and as) the context of black ontology, especially Black and Blur, ch. 23 and 24 .

25. On the significance of Zora in Du Bois's body of work, see McKay 244; for a dimmer view of Zora’s characterization, see Schmidt 193.

26. See also Hall's important article on lynching, sexual violence, and the history of Jim Crow photography.

27. In "propagandism" I mean to evoke Du Bois's "Criteria": "whatever art I have for writing has been used always for propaganda for gaining the right of black folk to love and enjoy" (1000).

\section{Works Cited}

Agha, Asif. "Voice, Footing, Enregisterment." Journal of Linguistic Anthropology 15.1 (2005): $38-59$.

Andrews, William L., ed. Critical Essays on W. E. B. Du Bois. Boston: G. K. Hall \& Co., 1985.

. Introduction to Du Bois, Quest, xxv-xxvii.

Baker, Houston A., Jr. Long Black Song: Essays in Black American Literature and Culture. 1972. Charlottesville: Univ. of Virginia Press, 1990.

Bakhtin, Mikhail. Problems of Dostoevsky's Poetics. Edited and translated by Caryl Emerson. Minneapolis: Univ. of Minnesota Press, 1993.

Beckert, Sven. Empire of Cotton: A Global History. New York: Knopf, 2015. 


\section{Alex Benson}

Bell, Bernard W. The Afro-American Novel and Its Tradition. Amherst: Univ. of Massachusetts Press, 1989.

Benveniste, Émile. Problems in General Linguistics. Translated by Mary Elizabeth Meek. Coral Gables, FL: Univ. of Miami Press, 1971.

Best, Stephen M. The Fugitive's Properties: Law and the Poetics of Possession. Chicago: Chicago Univ. Press, 2004.

Brontë, Charlotte. Jane Eyre. 1847. Chicago: Donnohue, Henneberry \& Co., 1890.

Brooks, Gwendolyn. "We Real Cool.” In Selected Poems, 73. New York: Harper and Row, 1963.

Brown, Adrienne and Britt Rusert. Introduction to "The Princess Steel" by W. E. B. Du Bois. PMLA 30.3 (May 2015): 819-29.

Brown, Bill. A Sense of Things: The Object Matter of American Literature. Chicago: Univ. of Chicago Press, 2003.

Byerman, Keith E. Seizing the Word: History, Art, and Self in the Work of W. E. B. Du Bois. Athens, GA: Univ. of Georgia Press, 2010.

Delany, Samuel R. Dhalgren. 1975. New York: Vintage, 2001.

Dickinson, Emily. "Tell all the truth but tell it slant" (poem 1129). In The Complete Poems of Emily Dickinson, edited by Thomas H. Johnson, 506-7. Boston: Little, Brown and Co., 1960.

Du Bois, W. E. B. Black Reconstruction: An Essay Toward a History of the Part Which Black People Played in the Attempt to Reconstruct Democracy in America. 1935. In The Oxford W. E. B. Du Bois, edited by Henry Louis Gates, Jr., introduction by David Levering Lewis. Oxford: Oxford Univ. Press, 2014.

. "Criteria of Negro Art.” 1926. In Writings, edited by Nathan Huggins, 993-1002. New York: Library of America, 1986.

D. Darkwater: Voices from Within the Veil. New York: Harcourt, Brace and Howe, 1920.

Dusk of Dawn: An Essay Toward an Autobiography of a Race Concept. 1940. In The Oxford W. E. B. Du Bois, edited by Henry Louis Gates, Jr., introduction by K. Anthony Appiah. Oxford: Oxford Univ. Press, 2014.

. The Quest of the Silver Fleece. 1911. In The Oxford W. E. B. Du Bois, edited by Henry Louis Gates, Jr., introduction by William L. Andrews. Oxford: Oxford Univ. Press, 2013.

- The Souls of Black Folk. 1903. In The Oxford W. E. B. Du Bois, edited by Henry Louis Gates, Jr., introduction by Arnold Rampersad. Oxford: Oxford University Press, 2009.

—. "The Souls of White Folk." The Independent 69 (1910): 339-42.

_. "Strivings of the Negro People." The Atlantic 80.478 (August 1897): 194-97.

Elder, Arlene A. “Swamp Versus Plantation: Symbolic Structure in W. E. B. Du Bois' The Quest of the Silver Fleece." Phylon 34.4 (1973): 358-67.

Fludernik, Monika. “How Natural Is 'Unnatural Narratology'; or, What Is Unnatural about Unnatural Narratology?" Narrative 20.3 (Oct. 2012): 357-70.

Frankenberg, Ruth. "The Mirage of an Unmarked Whiteness." In The Making and Unmaking of Whiteness, edited by Birgit Brander Rasmussen, Eric Klinenberg, Irene J. Nexica, and Matt Wray, 72-96. Durham: Duke Univ. Press, 2001.

Gates, Henry Louis, Jr. “The Black Letters on the Sign: W. E. B. Du Bois and the Canon.” In Du Bois, Quest, xi-xxiv. 
. The Signifying Monkey: A Theory of African American Literary Criticism. New York: Oxford Univ. Press, 1988.

Gooding-Williams, Robert. In the Shadow of Du Bois: Afro-Modern Political Thought in America. Cambridge, MA: Harvard Univ. Press, 2009.

Hale, Dorothy J., ed. The Novel: An Anthology of Criticism and Theory, 1900-2000. Malden, MA: Blackwell, 2006.

- Social Formalism: The Novel in Theory from Henry James to the Present. Stanford: Stanford Univ. Press, 1998.

Hall, Jacquelyn Dowd. “"The Mind that Burns in Each Body’: Women, Rape, and Racial Violence.” In Powers of Desire: The Politics of Sexuality, edited by Ann Snitow, Christine Stansell, and Sharon Thompson, 328-49. New York: Monthly Press, 1983.

Harney, Stefano and Fred Moten. The Undercommons: Fugitive Study and Black Planning. Wivenhoe: Minor Compositions, 2013.

Hickman, Jared. Black Prometheus: Race and Radicalism in the Age of Atlantic Slavery. Oxford: Oxford Univ. Press, 2016.

Holt, Elizabeth M. Fictitious Capital: Silk, Cotton, and the Rise of the Arabic Novel. New York: Fordham Univ. Press, 2017.

Irvine, Judith. "Shadow Conversations: The Indeterminacy of Participant Roles." In Silverstein and Urban, eds., 131-59.

Johnson, Barbara. A World of Difference. Baltimore: Johns Hopkins Univ. Press, 1989.

Johnson, James Weldon. Autobiography of an Ex-Colored Man. 1912. New York: Penguin, 1990.

Kester, Howard. Revolt Among the Sharecroppers. 1936. Introduction by Alex Lichtenstein. Knoxville: Univ. of Tennessee Press, 1997.

Kunreuther, Laura. Voicing Subjects: Public Intimacy and Mediation in Kathmandu. Berkeley: Univ. of California Press, 2014.

Lucey, Michael. Never Say I: Sexuality and the First Person in Colette, Gide, and Proust. Durham: Duke Univ. Press, 2006.

Lucey, Michael, Tom McEnaney, and Tristram Wolff, eds., Representations 137, Language-in-Use and the Literary Artifact (Winter 2017).

Marable, Manning. W. E. B. Du Bois, Black Radical Democrat. New York: Twayne Publishers, 1986.

McInnis, Jarvis C. "'Behold the Land': W. E. B. Du Bois, Cotton Futures, and the Afterlife of the Plantation in the US South.” The Global South 10.2, Plantation Modernity (Fall 2016): 70-98.

McKay, Nellie Y. "W. E. B. Du Bois: The Black Women in His Writings-Selected Fictional and Autobiographical Portraits.” In Andrews, Essays, 230-52.

McLanahan, Annie. Dead Pledges: Debt, Crisis, and Twenty-First Century Culture. Stanford: Stanford Univ. Press, 2017.

Milton, John. Paradise Lost. 1667. London: George Routledge and Sons, 1905.

Morton, Timothy. Hyperobjects: Philosophy and Ecology after the End of the World. Minneapolis: Univ. of Minnesota Press, 2013.

Moten, Fred. Black and Blur (consent not to be a single being). Durham: Duke Univ. Press, 2017.

Napolin, Julie Beth. "Elliptical Sound: Audibility and the Space of Reading." In Sounding Modernism: Rhythm and Sonic Mediation in Modern Literature and Film, edited by Julian Murphet, Helen Groth, and Penelope Hone, 109-130. Edinburgh: Edinburgh Univ. Press, 2017. 


\section{Alex Benson}

Pietz, William. "The problem of the fetish, I." RES: Journal of Anthropology and Aesthetics 9 (1985): 5-17.

Rampersad, Arnold. “W. E. B. Du Bois as a Man of Literature.” In Andrews, Essays, 49-66.

Reed, Adolph L. Jr. W. E. B. Du Bois and American Political Thought. New York: Oxford Univ. Press, 1997.

Richardson, Brian. Unnatural Narrative: Theory, History, and Practice. Columbus: Ohio State Univ. Press, 2015.

Schmidt, Peter. Sitting in Darkness: New South Fiction, Education, and the Rise of Jim Crow Colonialism, 1865-1920. Jackson: Univ. Press of Mississippi, 2010.

Silverstein, Michael. "Indexical Order and the Dialectics of Sociolinguistic Life." Language \& Communication 23 (2003): 193-229.

Silverstein, Michael and Greg Urban, eds. Natural Histories of Discourse. Chicago: Univ. of Chicago Press, 1996.

Spillers, Hortense J. “Mama’s Baby, Papa’s Maybe: An American Grammar Book.” diacritics 17.2, Culture and Countermemory: The "American" Connection (Summer 1987): 65-81.

Stoever, Jennifer Lynn. "Fine-Tuning the Sonic Color-line: Radio and the Acousmatic Du Bois." Modernist Cultures 10.1 (2015): 99-118.

Tsing, Anna. "Earth Stalked by Man.” The Cambridge Journal of Anthropology 34.1 (Spring 2016): $2-16$.

Urban, Greg. “The 'I' of discourse.” In Semiotics, Self, and Society, edited by Benjamin Lee and Greg Urban, 27-51. Berlin: Mouton de Gruyter, 1989.

Vološinov, V. N. Marxism and the Philosophy of Language. Cambridge, MA: Harvard Univ. Press, 1973.

Wall, Cheryl A. "Resounding Souls: Du Bois and the African American Literary Tradition." Public Culture 17.2 (2005): 217-34. 